\title{
An observational study of critical care physicians' assessment and decision-making practices in response to patient referrals
}

\section{Charlesworth, ${ }^{1}$ M. Mort ${ }^{2}$ and A. F. Smith ${ }^{3}$}

1 NIHR Academic Clinical Fellow, Lancaster Medical School, Lancaster University, Lancaster, UK, mda05mc@gmail.com

2 Professor of Sociology, Department of Sociology, Lancaster University, Lancaster, UK, M.Mort@Lancaster.ac.uk

3 Consultant Anaesthetist, Royal Lancaster Infirmary, Lancaster, UK, Andrew.Smith@mbht.nhs.uk

\section{Summary}

Previous studies of critical care admissions have largely compared patients that have been granted or declined admission. To better understand the decision process itself, our ethnographic approach combined observation of and interviews with critical care physicians in a large English hospital. We observed 30 critical care doctors manage 71 referrals and conducted 10 interviews with senior decision makers to explore the themes raised in the observations. Data were analysed using the constant comparative method. We found that the decision to move a patient to critical care was just one way in which the trajectory of critical illness could be modified. When patients were admitted to critical care, it was not always for invasive monitoring or advanced organ support, with some admitted for more general medical and/or nursing care. When patients were declined admission, they were not simply forgotten or left behind; they nevertheless underwent careful assessment and follow-up. Thus, depicting admission or refusal as a binary event is misleading. We suggest that prescriptive admission algorithms are problematic for clinicians, in that they may not take into account the complexity of clinical practice.

Correspondence to: M. Charlesworth

Email: mda05mc@gmail.com

Phone: 07468429531

Lancaster Medical School

Faculty of Health and Medicine

Lancaster University

Bailrigg, Lancaster, LA1 4YW

MeSH Keywords; Admitting Department, Hospital. Critical Care. Decision-making. Ethnography. 


\section{Introduction}

The absence of explicit rules regarding who should be admitted to a critical care bed may arguably cause confusion and frustration when medical teams seek admission for deteriorating inpatients. Referrers may perceive decisions as arbitrary or unfair and as such, may desire a formal decision tree to direct the process. Put simply however, it is not possible to admit every inpatient that is referred and not every patient can benefit from an admission. The study of how patients come to be identified as appropriate for admission and the logistics of how to organise their timely transfer has not, we believe, been sufficiently addressed by previous studies.

The evidence for the benefit of timely admission to critical care is irrefutable [1-3], yet little is known of the processes through which decisions are made. The UK has one of the smallest numbers of critical care beds per capita in the developed world, placing considerable pressure on clinicians' decision to admit [4]. Capacity in critical care is under constant pressure, though there has been a modest rise in the number of beds in England over the last five years [5]. Despite this increase, occupancy is consistently around $85 \%$, necessitating elective surgery cancellations and the transfer of patients between units [5].

The Department of Health's 1996 guideline outlines the types of patients who may benefit from critical care [6], though how relevant these remain in 2016 is debatable. In this guideline, a decision-tree with considerations such as illness reversibility, co-morbidities, advanced directives and the requirement for advanced organ support direct the decision either to continue ward care or admit to HDU or ICU. Our systematic review of research into the decision-making process over the last 20 years reported an incomplete and confused picture, that is difficult to relate with and apply to current practice due to their limitations [7]. Included studies either sought to link quantitative or categorical data to the decision outcome, or used surveys with closed questions to assess fictional scenarios where a decision about admission was required. Most were conducted outside the UK and demonstrate variation in admission rates, patient populations, working practices and factors reported to affect decision-making [7].

The decision to admit to critical care carries great weight to all parties and although the clinical, financial and affective consequences can be substantial, the processes leading to the decision remain unexamined [7]. To address this gap in understanding, we examined, through observation of clinical practice and in-depth interviews with clinicians, the dynamics of the interface between critical care and the hospital as a whole. Our goal was to gain understanding of the ways in which critical care physicians reach a decision to admit or decline the patients referred to them for an unplanned admission. 


\section{Methods}

The Lancaster University Research Ethics Committee granted ethical approval for all study procedures on the $3^{\text {rd }}$ of March 2015 (ref. 7034). The host site granted NHS Research and Development approval on the $15^{\text {th }}$ of January 2015. A Local NHS Research Ethics Committee examined the study protocol and advised that the design lay outside its scope, according to GAfREC guidelines [8].

The study was conducted on one site, a large teaching hospital with multiple tertiary specialities in the North West of England. An initial information session was run in the host department by MC and AS one month prior to commencement. Inclusion criteria were all doctors involved in the decision-making process. The participant information sheet was widely distributed at the host site and we obtained written consent to observe and/or interview individuals. Data collection initially focussed upon detailed observation of decision-making processes with regards unplanned referrals to critical care. Elective and planned work was excluded and not observed. A purposive sampling strategy was employed so as to observe as many different individuals as possible managing a wide breadth of cases. Following the completion of all observations, a series of in-depth interviews with senior decision-makers was conducted.

Observations were conducted across a spectrum of weekday, weekend, day, evening and night shifts. The main focus of data capture was of interactions between staff in the period following referral to the time of decision to grant or decline admission. Field notes were recorded in real-time and reviewed and expanded immediately after each observation ended. In-depth interviewing was focused upon all themes emerging from the analysis of observation field notes. Respondents were also asked to discuss a past case that they had found challenging. Interviews were recorded and transcribed verbatim. Data collection (by MC) continued until 'saturation' was achieved, where no new themes emerged [9].

All data were managed using 'NVivo 10 for Mac' software [10]. Using a grounded theory approach, analysis was performed in an iterative process concurrently with data collection [11]. We continually looked for similarities and differences in the data, within and across transcripts and this informed subsequent data collection [9]. By performing these cross-comparisons, we established analytical categories and selected key overarching concepts, meeting regularly as a group to discuss the framework with which to interpret the data. Finally, participants were presented with the initial analysis and a summary of key findings in order to provide respondent validation.

The study does not aim to identify differences between the approaches of individual clinicians or regional/national practice variations. 


\section{Results}

The observations took place in a large teaching hospital with multiple tertiary specialties and 40 critical care beds, split equally between ICU and HDU. ICU and HDU were separate spaces with separate medical and nursing staff allocations. Level 3 care was never stretched to HDU, with all such patients cared for in ICU and capacity determined by bed spaces and staffing numbers. There were a number of observed practices relevant to the way in which referrals were processed and through which decisions were made. A dedicated critical care consultant was available during the day, throughout the week and weekend, whose primary role was to assess acute referrals from other areas of the hospital. This consultant would often spend three or four consecutive days in the role. The majority of the observations were carried out through the shadowing of this individual, or trainees under their supervision. If the consultant was not on-site, between midnight and morning, all referrals were discussed between the night trainee and the supervising consultant. The night consultant could be onsite within 30 minutes, if necessary. Referrals were directed through a dedicated phone or pager. On some occasions, referring doctors discussed cases in person. Patients were also 'flagged' to the referral consultant through an automated electronic track and trigger system, based on 'early warning score' parameters. Such alerts were dealt with by calling the ward, calling the medical team caring for the patient or by visiting the patient in person. It was possible to use an online system to display the current and historical physiological observations relating to the early warning score of any patient in the hospital from any location.

A total of 30 critical care doctors (17 consultants and 13 ST5+ trainees) were recruited. Detailed observations were conducted between May-September 2015 with typically 5-6 referrals per week. These comprised 71 referrals, of which 24 resulted in admission. Table 1 summarises these referrals in terms of age, diagnoses, time of observation and the observed physician(s) for each case. In order to focus on the emergent themes from the observation of these 71 referrals, 10 interviews were conducted with eight critical care consultants, one emergency medicine consultant and one senior medical trainee. The resulting data, in the form of transcripts from the observations and interviews, proved to be rich, with themes being plentiful and diverse. Key themes with their accompanying extracts have been selected to illustrate both the typical observations/responses collated and the diversity and breadth of the dataset.

\section{Summing the case}

Patient, physician and contextual factors strongly shaped the decision to transfer the patient to critical care. There were no absolute patient indications or contraindications for transfer to critical care. Instead, sets of relative indications and contraindications for admission were 'summed', with the overall balance swaying the eventual outcome (Extract 1). Despite their existence, the use of systems to differentiate survivors from non-survivors was not observed. Instead, observations suggested that a forecast was made based upon experience of previous similar cases.

\section{1 - Interview 5 - ICU Cons E:}

"I think mostly you're taking it as a whole package and weighing it up. I think as well there are sometimes when someone's got a systolic of fifty or they've got low arterial oxygen and they're on high oxygen, they're the ones 
who you are going to be, you're going to need a very good reason not to take them. So, I mean, well you can say there are definitive cut offs but you'd struggle because I think you still look at the complete package, whether critical care admission would benefit them. You can say that they need it, they may need organ support, but whether it will ultimately change the outcome for the patient, I guess that's where the overall picture comes in."

\section{Blurred care boundaries}

When patients were moved to critical care, this was not always for the purpose of invasive monitoring or advanced organ support. In addition to possessing the ability to provide this advanced care, critical care is well resourced in terms of medical and nursing staff. On several occasions, referrers sought admission due to difficulties in providing general nursing or medical care for patients on hospital wards (Extracts 2-3). The 'care' provided in this respect is more difficult to define and measure than more discrete levels of invasive monitoring or organ support. Likewise, when patients were declined admission, despite continuing ward level care, other forms of critical care was provided. These included, but were not limited to; a full physical examination, contributing to a management plan, advice regarding antibiotics or fluids, consideration of a care ceiling and discussing care with other parties, such as relatives. Thus, there is a paradoxical symmetry between those cared for on the ward who receive critical care interventions and those who are admitted to critical care for more general ward based medical or nursing care interventions.

\section{2- Observation 50:}

Ward Cons "Do you think HDU would be useful?"

ICU Cons "It probably wouldn't be a sensible idea to take him and intubate him for fluid management."

Ward Cons "We will try and encourage oral fluids. If he keeps on triggering though it is a drain on the care time that the nurses can give the other patients. Therefore, I am asking, please can you take him to help us out?"

ICU Cons "But if we took him, we wouldn't do anything differently. He doesn't need organ support or invasive monitoring."

Ward Cons "I appreciate that, but from a care point of view, we are understaffed and when we have staffing issues, patients like this make it more difficult."

\section{3 - Interview 9 - Senior Medical Trainee:}

"I think from the doctor side of things, I'm happy to review a patient ten times a day if that's required, I don't think that from my point of view it would make a difference, medical wise, but nurses, certainly, as soon as they are doing hourly obs, there's pressure as to 'is this patient in the right place of care?' and, often that's because they don't get support from their other nursing colleagues, or ward managers perhaps in terms of looking after their other patients, it's not that they don't want to provide that level of care or they don't think that patient is sick and needs them, it's just that their other seven patients tend to suffer an awful lot and they don't get pain relief, meds or whatever on time, don't get washed, and then that becomes, a sort of pressure on that side of things becomes 'oh well do you not think they should be in high level of care for the nursing care and the obs alone?' that can be a bit of a funny call as well."

\section{Visibility}

On some occasions, patients or their problems became more 'visible' when they were referred to critical care (Extract 4). A critical care opinion usually involved a systematic process of information retrieval and a 'head-to-toe' physical examination. This process frequently illuminated missed opportunities, misdiagnoses and mismanagement (Extracts 5-6). Patients who were inpatients for a long time, were 'outlying' on other wards or who had been deemed fit for discharge were the least 'visible' to their doctors and other healthcare staff in this respect.

\section{4- Observation 5:}

The ICU consultant is busy with a problem on the ICU, so he asks his trainee to go and look at the patient. The trainee leaves the unit and arrives on the outpatient dialysis ward a short time later. When he arrives, there are three renal doctors present. They are all attempting to site an IV cannula. The patient has received some intravenous fluid, but prior to this, he became drowsy with a low respiratory rate. We are now just outside the patient's dialysis room. 
The ICU trainee explains to me that he is keen to know the details of the patient's admission. He establishes that this is a arteriopathic man with poorly controlled diabetes and a previous right leg amputation.

ICU Trainee "Is he distended? He looks it."

Dialysis Nurse "It's always like this. I don't think he's any more distended than normal."

ICU Trainee "So we think he has line related sepsis then?"

Three renal doctors all together say "Yes"

The ICU Trainee then performs a full clinical examination of the patient.

ICU Trainee "What about the bandages on the feet? What's that? This is the source of the sepsis isn't it?"

The ICU Trainee takes the bandage off the foot and this reveals severely gangrenous toes.

Renal Nurse "He has refused an amputation before I think."

ICU Trainee "I'm pretty sure this is the source of the sepsis. Let's get the vascular team to see him urgently."

5 - Observation 36:

Med Cons "This is a young man with known epilepsy. He's not taken his meds for two days now and came in with a seizure. He has been on ITU before at another hospital. So, we thought we'd get you guys involved early. So what happened is... he has not had his meds for two days and then he fitted at home so he came in to us. We wrote him up for his valproate but he fitted just now. It wouldn't stop. I gave him four of lorazapam twice, but it didn't stop so I gave him four more. We are now loading him with phenytoin. He needed that lorazapam. I know he might need to be intubated but we had no choice."

6 - Interview 4 - ICU Cons D:

"I can think of a case on a Sunday evening of a young chap who had a drug overdose and then got severe bronchospasm, and he was intubated and ventilated in resus, but he was getting, first of all he was getting inadequate treatment, so he wasn't getting enough of the drugs but he was actually getting the wrong treatment, and I went to the emergency department, after about an hour's resuscitation I think he had been intubated for an hour, he was just getting the wrong care. Systemically he was quite unwell, his $\mathrm{CO}_{2}$ was 16, his base deficit was minus 20 , or around those lines, his lactate was very high and he'd been undertreated."

\section{Consensus}

It was not our purpose to examine inter-physician variations, although some talk about differences emerged in the interviews. Respondents commonly perceived their peers to have a different approach from themselves, with some labeled as 'hawks' or 'doves'. Interestingly, in practice, lone decisionmaking was rare and decision-making by consensus was common; the interviews corroborated the overwhelming importance of this (Extract 7).

\section{7 - Interview 8 - ICU Cons H:}

"The other change that has come on in the last few years that is probably worthy of talking to you about is the collaborative way in which we make the decisions now. That is quite different to before. We used to accept the lone gun if you like, shooting from the hip. You are constantly adjusting your position, and I think that some people, there is still amongst the group, even as it grows, that there are some people that have a reputations as both hawks and those as doves. But actually the balance between, there is a dynamic thing over individual decisions and we will still check admission with each other, not necessarily for the ones we decline, more for the ones we admit. What do you think about admitting this one? Is it too soft? Is it too hard? It is a supportive thing, what's good about having the number of us on that we do, during the day, is that you will often be on with a different person as well. So you are not checking same with same, you haven't got two hawks all the time, it makes it a very supportive environment to work and pushes a decision which is more likely to be the correct one for that individual patient."

\section{Negotiation}

A process of negotiation between critical care and parent team doctors was common. Negotiations usually centred on whether the patient should be admitted, what level of care should be provided and what interventions were or were not appropriate (Extract 8-10). The observation of conflict between doctors was rare, with two examples captured. The outcome for both cases was admission, despite strong reservations from the critical care consultant body. When one patient was admitted in a context of unresolved conflict, a 'quasi-religious process' was observed. First, there was absolution for the referring clinician's 'mistakes' (e.g. performing a high-risk intervention in a high-risk patient). There was forgiveness for poor care and/or judgment, forbearance towards admission rebuttal and then, following admission, a state of transfiguration, where there was an immediate change of state for the 
patient, possibly through better general nursing or medical care. This was then coupled with the prospect of redemption through cheating death, albeit for a short time period.

8 - Observation 7:

ICU Cons to Ward Cons "It doesn't alter my experience, that if you have advanced renal failure, myeloma, a bone marrow transplant and you're in your seventies and ventilated. I don't know anyone that has survived like that. I am happy to take him for vasopressors, filtration and non-invasive ventilation though."

\section{9 - Observation 58:}

ICU Cons "In my experience, people with metastatic pancreatic cancer don't get better from being put on a ventilator on ICU. I would suggest that if she arrested, she would not survive. I would also suggest that she should not be ventilated in critical care."

Ward SpR "Is there a halfway house where we can, say, let's use non-invasive ventilation as a ceiling of care? If it doesn't work, then she wouldn't then be for ventilation? It's just that there is a difference of opinion amongst the surgical consultants."

ICU cons "I'm happy to sit in with the consultant and the family and discuss these things. I can also speak to my colleagues to get some consensus. I think the consensus should be that we wouldn't ventilate her but we would consider non-invasive ventilation. We are giving her the right treatment for now and this is all considering what we are doing next. Call your consultant and then call me after."

\section{0 - Interview 7 - ICU Cons G:}

"You don't go down and say, 'Hi, critical care here and this is ridiculous, why are you referring this, not for ICU, bang, that's it, book closed'...its, 'l've come down, l've spent some time assessing your patient, this is my opinion, I think the best treatment is, fluids, potassium, observation, and when he is stable enough, you can put him on dialysis', not, 'I think you need to fill him up first'. And all these things, you put it like that, and they know they should be doing these things anyway, so, we're not, it's not a turf war between us in any way, and I think, being supportive to them, and supporting their plan or agreeing the plan between teams, is much more constructive."

\section{Environment}

Wider contextual factors played a major role in the decision to admit. The number of available beds in critical care was a constant pressure on decision-makers (Extracts 12,13). Conversations around capacity and the balancing of elective surgery with unplanned referrals were commonly observed. A crucial observation was of how decision-making altered at times of high and low occupancy (Extract 14). If a patient was appropriate for admission, they were admitted: if there was no space for that patient, they were taken to theatre recovery or resuscitation. For patients, where their admission appropriateness was unclear, at times of low bed occupancy, the threshold for their admission would be lower. During times of high bed occupancy, these patients were triaged and the threshold for admission was higher. They may receive a simple therapy, such as a fluid bolus or chest physiotherapy, with their response determining the likelihood of admission. This process introduced a stage of hypothesis testing and triage, where the doctor employed clinical skill to determine how best to use their resources in the safest possible manner. On rare occasions however, this does not work effectively and causes problems (Extract 15). Hospital geography played a key role in the process of safe triage (Extract 12). A spectrum of geographical safety existed whereby some locations, such as the resuscitation area of the emergency department or the recovery area of theatres were seen as safer for critically unwell patients to be 'held', as opposed to an acute medical unit or a haematology ward. Areas such as a surgical ward, an elective treatment centre or a rehabilitation unit were perceived as unsafe for those with critical illness. Patients deemed to be in an unsafe environment were more likely to be rapidly transferred, or taken to a place of relative safety.

\section{2 - Observation 15:}

ICU is currently full, so the ICU Trainee calls the ICU Consultant for assistance and then arranges a bed space in theatre recovery to take the patient immediately. ICU Cons arrives very quickly "He needs to come to recovery as he is not in a safe place here currently. We need to get him off the ward."

\section{3 - Observation 23:}

ICU Cons to me "She definitely needs to come. You can hear her from here. She is working very hard and has noisy breathing. l'll arrange a bed." 
The ICU consultant then calls the ICU nurse in charge to arrange a bed for the haematology patient on the ward immediately for non-invasive ventilation "Please can we have a side-room? If she cannot come in the next thirty minutes, l'll have to take her to theatre recovery" and a status epilepticus patient in resuscitation "he needs to come at some stage. We need the CT head report first. Are we then full after that?"

ICU Nurse in Charge "Yes"

ICU Cons "I'll escalate it to the directorate manager so he knows we are going to be full soon. There's one more patient in resuscitation that could go either way but we'll have to wait and see. Will you call me back when you know more?"

The ICU consultant then calls the directorate manager and says, "Discharges should now be a priority as we will soon be full."

14 - Interview 3 - ICU Cons C:

"...you know when someone is on the cusp of Level One and Two, that you've got more rope and more margin for error haven't you? You've made a plan and seen the patient, and what happens is you should plan to review them, so if that patient deteriorates, you can still catch them and then bring them, whereas if you've got the patient who is on the borderline of needing Level Three care, well you need to step in and you haven't got the same scope for leaving them."

15 - Interview 10 - EM Cons:

"I don't use the term but some of my critical care colleagues use the term 'bed and breakfast'. These people often appear in the evening, they go to ITU overnight, wake them up in the morning and they go home. Who is right or wrong in this circumstance, I do not know. But what that meant was that we had quite a prolonged attempt at extubating this lady, so we turned all the sedation off, she had been on propofol and remifentanil if I remember rightly, and, it took her about 45 minutes to get to the point where she could raise her head off the bed, and it was deemed safe to extubate, by this time, critical care had turned up. My feeling was that in all honesty, to extubate this lady she is still going to need to go to HDU, she is still not GCS 15.

\section{Tacitly-held practices}

Usage of written local or national guidelines, policies or criteria to facilitate the decision-making process was seldom observed. During the interviews, justifications for the non-use of explicit admission criteria were explored (Extracts 16-18). What emerged was a picture of tacitly held criteria, that were neither too stringent nor too wide, yet could be adapted for the local circumstances. Expressions of support for this way of working were commonly stated, as was resistance towards the introduction of fixed prescriptive criteria or explicit rules.

\section{6 - Interview 2 - ICU Cons B:}

"...the idea is you have objective criteria, if you fulfil the criteria you get critical care. Well we then have the responsibility to provide it. And, if the criteria are wide enough, then we break the system. At the moment we have a very fuzzy system, which means that our bed occupancy is very high because if we have beds, we will use them, if we are tight for beds, then we will make decisions slightly differently, but it then means that we use most of our resources most of the time, and probably, that, that's as good as it gets. Sometimes it will be a little bit unfair, and sometimes it will be very generous. But on balance, that is probably how you use the resources the best."

\section{7 - Interview 7 - ICU Cons G:}

"As soon as you make rules about this sort of thing, admission criteria, you make a rod for your own back, and as you quite rightly say, you will end up excluding people who should come and may include people who probably do not need to come, so, because it is such a subjective decision to a certain extent, although we try to look at it objectively, a lot is about context, so yes, it does need to be a human experienced clinician making the decision, we haven't found any protocol or mathematical model to answer it for us, and generally overall I think in this unit if the people that need critical care and who are appropriate for critical care, they get here within a few hours. That is something we have noticeably improved in in the last five years."

\section{8 - Interview 4 - ICU Cons D:}

"We produce good doctors and then we produce good intensive care doctors. So, l'm reliant really on that. Protocols and policies for admission and discharge would not be something that the medical profession would wish, it may come from outside the medical profession, but I think it will be resisted. We admit people on the basis of need." 


\section{Discussion}

Following referral to critical care, the assessment of the patient uncovered the story of events leading to the referral, thus allowing a patient trajectory to be constructed. The decisions that followed aimed to modify that trajectory and included many possible outcomes; moving the patient to critical care was only one of these. Other outcomes included, but were not limited to; advising or issuing limitations on care, managing an end of life issue, delivering a medical intervention, contributing advice regarding further investigations or management and discussing care with other parties. This qualitative study found that the observable moment of decision to admit to critical care played a minor role in the overall process following the referral of inpatients. Admitted patients were not exclusively moved to critical care for invasive monitoring or advanced organ support during the treatment of reversible pathology. Some were admitted for general medical and/or nursing care, some for end of life care and others due to difficulties in delivering that care in a ward based environment. Many who were not admitted received other, often 'softer' and less quantifiable forms of critical care input in a ward based setting. Thus, blurred boundaries exist in which care is distributed in ways that challenge any simple comparison between the admitted/not admitted binary.

There are several areas where our findings differ from those of previously published research in this area. These studies are overwhelmingly quantitative in design and our study represents the first use of ethnographic methods to explore this complex topic. In examining decision making we would argue that a major strength of our study is that "ethnography has the power to reach the parts that other methods cannot' [12]. There are four key areas that illustrate this.

Firstly, bed capacity and resource limitations have been widely implicated as strongly influencing the likelihood of admission to critical care [13-16]. In particular, Stelfox proposed in 2012 that bed capacity fundamentally changes the way in which referred patients are cared for [15]. We argue that bed capacity is an important factor that pressurises the system, but the way in which this is dealt with has evolved to become more complex than has been previously proposed. Supply and demand mismatch does indeed affect admission decisions, but those who are not admitted are not simply forgotten or left behind. Thus, we found that critical care was given to patients that needed it regardless of bed capacity. If there was a need for advanced organ support or invasive monitoring, a way of providing this was found through means of judicious flexibility.

Secondly, previous research has used quantitative and categorical comparisons in an attempt to link patient symptoms, physiology or diagnoses with admission decisions in a linear manner [13-21]. We argue that these attempts have had limited successes, as they are not well suited to this enquiry. Our qualitative approach has demonstrated that rather than a collection of single factors signposting decision outcomes, decisions are case-by-case judgments based upon the complex weighing of evidence, benefit and risk for and against admission. Moreover, the moment of decision to admit to critical care is, itself, of limited importance and only one of very many outcomes from referral. We argue that comparing those granted or declined admission in this way is an oversimplification. 
Thirdly, we are able to demonstrate the arguments against the introduction of further, more explicit, admission criteria to facilitate decisions. Defining explicit rules may support many clinically complex or pressured decisions, and examples have been published elsewhere [22-24]. We argue that, currently, it is impractical to define such criteria for critical care admission decisions and there is no proven substitute for mature clinical judgment.

Finally, a structured model for decision making relevant to complex clinical scenarios has been proposed elsewhere [25]. We would argue that this approach to decision-making, whilst it may be applicable to most other areas of practice, is not suited to critical care admission decisions. Whilst this could suggest that such decisions are unstructured and haphazard, our study shows however, that there is an underlying structure in decision-making that has multiple complexly interrelated components.

Our study therefore, has important implications for practice. As more pressures are placed upon budgets and as the supply and demand gap for bed-space widens, it may be tempting to introduce rules, standards and guidelines for admission to critical care. The use of guidelines in any particular area of practice is controversial and has been discussed elsewhere [26]. Admission guidelines with rigid criteria may cause potential harm to patients and may not help clinicians. Any such guidance would have to acknowledge the tacit processes highlighted herein. We encourage the critical care community to be aware of these tacit processes that govern admission to critical care and how they may affect their individual or organisational practices.

With regards to further research, we argue that the use of studies that compare patients who are admitted or declined are no longer useful. The traditional model of identifying patients for admission to critical care, for invasive monitoring and/or organ support, during the treatment of reversible pathology [6], is arguably no longer an accurate refection of practice. Those that are not admitted to critical care are still cared for. A critical care opinion, a simple intervention, input with regards investigation or management, discussions with relatives, a plan for follow-up and all the other practices that result from a referral are all forms of critical care that patients in a critical care unit receive. As such, there is a need for studies that reach beyond the boundaries of critical care as a defined space and consider critical illness in all corners of the hospital.

Our study provides a basis for further work that can improve the education of doctors who refer patients to critical care, aid those who are practicing the art of decision-making and afford a better understanding of these processes at a time of increasing demand. The progression through which senior doctors acquire the expertise with regards managing unplanned referrals forms part of the hidden curriculum and such knowledge and practices are tacitly transferred. Unmasking these processes could allow for a more structured approach to what is a complex and sensitive area of practice. Such further work could attend to areas such as how the seniority or experience of the 
decision maker influences their practice and how their views change with time. The views and opinions of patients, relatives and other healthcare professionals with regards critical care admission could contribute to this understanding. The role of palliative care and end of life decision-making for patients referred to critical care could be studied. Rather than the study of decision making for referred patients, the way in which these patients are referred, for example the seniority of referrer and the quality of information provided could be examined. The influence of critical incidents around the decision to admit could be studied with regards how this shapes local practices. Finally, an examination of decision-making around discharge from critical care and the logistical difficulties in discharging appropriate patients to a ward could also add to our understanding of this topic.

\section{Acknowledgments}

The authors acknowledge Dr Cliff Shelton, NIHR Doctoral Research Fellow at Lancaster Medical School, for his comments on an earlier draft of the manuscript.

\section{Funding and Competing Interests}

No external funding and no competing interests declared.

\section{References}

1. Cardoso LT, Grion CM, Matsuo T, et al. Impact of delayed admission to intensive care units on mortality of critically ill patients: a cohort study. Critical Care 2011; 15: R28.

2. Harris S, Singer M, Rowan K, Sanderson C Delay to admission to critical care and mortality among deteriorating ward patients in UK hospitals: a multicentre, prospective, observational cohort study. Lancet 2015; 385: S40.

3. McQuillan P, Pilkington S, Allan A, et al. Confidential inquiry into quality of care before admission to intensive care. British Medical Journal 1998; 316: 1853-8.

4. Adhikari NK, Fowler RA, Bhagwanjee S, Rubenfeld GD Critical care and the global burden of critical illness in adults. Lancet 2010; 376: 1339-46.

5. NHS England Critical Care Bed Capacity and Urgent Operations Cancelled 2015-16 Data. http://www.england.nhs.uk/statistics/statistical-work-areas/critical-care-capacity/critical-care-bedcapacity-and-urgent-operations-cancelled-2015-16-data/ (accessed 10th Jan 2016).

6. Department of Health. Guidelines on admission to and discharge from Intensive Care and High dependency Units, 1996.

7. Charlesworth M, Smith AF The decision to admit to critical care: time for a re-think? Anaesthesia 2016; 71: 61.

8. GAfREC guidelines http://www.hra.nhs.uk/resources/research-legislation-and-governance/governancearrangements-for-research-ethics-committees/ Accessed 28/08/2015.

9. $\quad$ Bowen G Naturalistic inquiry and the saturation concept: a research note. Qualitative Research 2008; 8: 137-52.

10. NVivo qualitative data analysis Software; QSR International Pty Ltd. Version 10, 2014.

11. Bryant A, Charmaz K The SAGE Handbook of Grounded Theory. SAGE Publications. 2010.

12. Pope C, Mays N Reaching the parts other methods cannot reach: an introduction to qualitative methods in health and health services research. British Medical Journal 1995; 311: 42-5.

13. Escher M, Perneger TV, Chevrolet JC National questionnaire survey on what influences doctors' decisions about admission to intensive care. British Medical Journal 2004; 329: 425.

14. Iapichino G, Corbella D, Minelli C, et al. Reasons for refusal of admission to intensive care and impact on mortality. Intensive Care Med 2010; 36: 1772-9.

15. Stelfox HT, Hemmelgarn BR, Bagshaw SM, et al. Intensive care unit bed availability and outcomes for hospitalized patients with sudden clinical deterioration. Arch Intern Med 2012; 172: 467-74.

16. Garrouste-Orgeas M, Montuclard L, Timsit JF, Misset B, Christias M, Carlet J Triaging patients to the ICU: a pilot study of factors influencing admission decisions and patient outcomes. Intensive Care Med 2003; 29: 774-81. 
17. Cohen RI, Eichorn A, Silver A Admission decisions to a medical intensive care unit are based on functional status rather than severity of illness. A single center experience. Minerva Anestesiol 2012; 78: 1226-33.

18. Cohen RI, Lisker GN, Eichorn A, Multz AS, Silver A The impact of do-not-resuscitate order on triage decisions to a medical intensive care unit. J Crit Care 2009; 24: 311-5.

19. Howe DC Observational study of admission and triage decisions for patients referred to a regional intensive care unit. Anaesth Intensive Care 2011; 39: 650-8.

20. Walter KL, Siegler M, Hall JB How decisions are made to admit patients to medical intensive care units (MICUs): A survey of MICU directors at academic medical centers across the United States. Critical Care Medicine 2008; 36: 414-20.

21. McNarry AF, Goldhill DR Intensive care admission decisions for a patient with limited survival prospects: a questionnaire and database analysis. Intensive Care Med 2004; 30: 325-30.

22. Mushambi MC, Kinsella SM, Popat M, et al. Obstetric Anaesthetists' Association and Difficult Airway Society guidelines for the management of difficult and failed tracheal intubation in obstetrics. Anaesthesia 2015; 70: 1286-306.

23. Rucklidge MW, Yentis SM Obstetric difficult airway guidelines - decision-making in critical situations. Anaesthesia 2015; 70: 1221-5.

24. Association of Anaesthetists of Great B, Ireland, Griffiths R, et al. Management of proximal femoral fractures 2011: Association of Anaesthetists of Great Britain and Ireland. Anaesthesia 2012; 67: 85-98.

25. Yentis SM Decision analysis in anaesthesia: a tool for developing and analysing clinical management plans. Anaesthesia 2006; 61: 651-8.

26. Griffiths R, Shinde S, Clyburn P 'Come together'. How the AAGBI reaches consensus over its guidelines. Anaesthesia 2016; 71: 261-4. 
Table 1 Summary of observations by case and admission outcome to illustrate the breadth of cases, time-periods and participants observed.

\begin{tabular}{|c|c|c|c|c|}
\hline \multicolumn{5}{|c|}{ Referrals resulting in admission to critical care } \\
\hline $\begin{array}{l}\text { Case } \\
\text { Number }\end{array}$ & Age & Clinical Vignette & $\begin{array}{c}\text { Time } \\
\text { Observed }\end{array}$ & $\begin{array}{l}\text { Physician } \\
\text { Observed }\end{array}$ \\
\hline 1 & $60 \mathrm{~s}$ & $\begin{array}{l}\text { Non-hodgkins lymphoma with biliary obstruction and a raised } \\
\text { venous lactate. }\end{array}$ & $\begin{array}{l}\text { Weekday } \\
\text { evening }\end{array}$ & Consultant $1^{*}$ \\
\hline 2 & $40 \mathrm{~s}$ & $\begin{array}{l}\text { Hodgkins lymphoma, chest sepsis, unresponsive to fluid } \\
\text { boluses thus requiring vasopressors. }\end{array}$ & $\begin{array}{l}\text { Weekday } \\
\text { morning }\end{array}$ & Consultant 2 \\
\hline 3 & $60 \mathrm{~s}$ & $\begin{array}{l}\text { Non-hodgkins lymphoma and type one respiratory failure } \\
\text { secondary to chest sepsis. }\end{array}$ & $\begin{array}{l}\text { Weekday } \\
\text { morning }\end{array}$ & Consultant 2 \\
\hline 4 & $70 \mathrm{~s}$ & $\begin{array}{l}\text { Type two respiratory failure with acute kidney injury and normal } \\
\text { cardiac function. }\end{array}$ & $\begin{array}{l}\text { Weekday } \\
\text { morning }\end{array}$ & Consultant 2 \\
\hline 5 & $50 \mathrm{~s}$ & $\begin{array}{l}\text { End stage renal failure and peripheral vascular disease with } \\
\text { hypotensive episode and unresponsiveness during dialysis. } \\
\text { Diabetic foot sepsis diagnosed. }\end{array}$ & $\begin{array}{l}\text { Weekday } \\
\text { morning }\end{array}$ & $\begin{array}{c}\text { Consultant } 3^{*}, \\
\text { Trainee } 1\end{array}$ \\
\hline 6 & $50 \mathrm{~s}$ & $\begin{array}{l}\text { latrogenic hypokalameia following a renal transplant requiring } \\
\text { central potassium replacement. }\end{array}$ & $\begin{array}{l}\text { Weekday } \\
\text { morning }\end{array}$ & Consultant $3^{*}$ \\
\hline 7 & $70 \mathrm{~s}$ & $\begin{array}{l}\text { End stage renal failure, diabetes and myeloma with hypotension } \\
\text { and confusion following elective stem cell transplant. }\end{array}$ & $\begin{array}{l}\text { Weekday } \\
\text { morning }\end{array}$ & Consultant $3^{*}$ \\
\hline 8 & $50 \mathrm{~s}$ & $\begin{array}{l}\text { Diabetic foot sepsis with hypotension referred from the vascular } \\
\qquad \text { outpatient clinic. }\end{array}$ & $\begin{array}{l}\text { Weekday } \\
\text { morning }\end{array}$ & Consultant $4^{*}$ \\
\hline 9 & $40 \mathrm{~s}$ & $\begin{array}{l}\text { Chest sepsis in an immmunocompromised patient with } \\
\text { leukaemia. }\end{array}$ & $\begin{array}{l}\text { Weekday } \\
\text { evening }\end{array}$ & Consultant $4^{*}$ \\
\hline 10 & $60 \mathrm{~s}$ & $\begin{array}{l}\text { Out of hospital cardiac arrest. Not for percutaneous coronary } \\
\text { intervention despite dynamic cardiovascular instability. }\end{array}$ & $\begin{array}{l}\text { Weekday } \\
\text { night }\end{array}$ & Consultant $3^{*}$ \\
\hline 11 & $80 \mathrm{~s}$ & $\begin{array}{l}\text { Acute deterioration several days following elective bowel } \\
\text { resection. Required RSI on the ward and immediate transfer to } \\
\text { critical care. }\end{array}$ & $\begin{array}{l}\text { Weekday } \\
\text { morning }\end{array}$ & Consultant $1^{*}$ \\
\hline 12 & $40 \mathrm{~s}$ & $\begin{array}{l}\text { Out of hospital cardiac arrest, non-ischaemic cardiomyopathy } \\
\text { and low ejection fraction. }\end{array}$ & $\begin{array}{l}\text { Weekday } \\
\text { evening }\end{array}$ & Consultant $3^{*}$ \\
\hline 13 & $20 \mathrm{~s}$ & $\begin{array}{l}\text { Recreational overdose and unconsciousness. Required RSI in } \\
\text { the ED, CT head scan and transfer to ICU. }\end{array}$ & $\begin{array}{l}\text { Weekday } \\
\text { morning }\end{array}$ & $\begin{array}{l}\text { Consultant } 5 \text {, } \\
\text { Trainee } 2\end{array}$ \\
\hline 14 & $70 \mathrm{~s}$ & $\begin{array}{l}\text { Blocked urostomy, acute kidney injury, hypotension, urinary- } \\
\text { tract sepsis and vasopressors started in the ED. }\end{array}$ & $\begin{array}{l}\text { Weekday } \\
\text { evening }\end{array}$ & Consultant 2 \\
\hline 15 & $70 \mathrm{~s}$ & $\begin{array}{l}\text { Dislodged tracheostomy tube several weeks post-laryngectomy } \\
\text { with hypoxia. Stablised in theatre recovery. }\end{array}$ & $\begin{array}{l}\text { Weekday } \\
\text { morning }\end{array}$ & Consultant 2 \\
\hline 16 & $50 \mathrm{~s}$ & $\begin{array}{l}\text { Immunocompromised patient with respiratory failure and } \\
\text { multiple previous ICU admissions. }\end{array}$ & $\begin{array}{l}\text { Weekday } \\
\text { morning }\end{array}$ & Consultant 5 \\
\hline 17 & $50 \mathrm{~s}$ & $\begin{array}{l}\text { Respiratory arrest in a patient with COPD. Required RSI on the } \\
\text { medical ward. }\end{array}$ & $\begin{array}{l}\text { Weekday } \\
\text { morning }\end{array}$ & Consultant 6 \\
\hline 18 & $50 \mathrm{~s}$ & $\begin{array}{l}\text { Acute abdomen following elective cholecystectomy. Stablised in } \\
\qquad \text { ICU prior to theatre. }\end{array}$ & $\begin{array}{l}\text { Weekday } \\
\text { evening }\end{array}$ & Consultant $3^{*}$ \\
\hline 19 & $50 \mathrm{~s}$ & $\begin{array}{l}\text { Upper gastrointestinal haemorrhage with high venous lactate } \\
\text { and a severe metabolic acidosis. }\end{array}$ & $\begin{array}{l}\text { Weekend } \\
\text { morning }\end{array}$ & Consultant $3^{*}$ \\
\hline 20 & $20 \mathrm{~s}$ & $\begin{array}{l}\text { Mixed overdose of prescription medication with reduced } \\
\text { conscious level. }\end{array}$ & $\begin{array}{l}\text { Weekend } \\
\text { evening }\end{array}$ & Consultant 7 \\
\hline
\end{tabular}




\begin{tabular}{|c|c|c|c|c|}
\hline $\mathbf{2 1}$ & 30s & $\begin{array}{r}\text { Parturient with intra-abdominal bleeding from a fibroid uterus, } \\
\text { deranged electrolytes and venous gases. }\end{array}$ & $\begin{array}{c}\text { Weekday } \\
\text { morning }\end{array}$ & Consultant $4^{*}$ \\
\hline $\mathbf{2 2}$ & 60s & $\begin{array}{c}\text { Type one respiratory failure with multiple co-morbidities, acute } \\
\text { kidney injury, and poor functional capacity requiring non- } \\
\text { invasive ventilation. }\end{array}$ & $\begin{array}{c}\text { Weekday } \\
\text { morning }\end{array}$ & Consultant 3* \\
\hline $\mathbf{2 3}$ & $50 \mathrm{~s}$ & $\begin{array}{c}\text { Status epilepticus with a high BMI requiring RSI, CT head and } \\
\text { transfer to ICU. }\end{array}$ & $\begin{array}{c}\text { Weekday } \\
\text { night }\end{array}$ & $\begin{array}{c}\text { Consultant 8, } \\
\text { Trainee 3 }\end{array}$ \\
\hline $\mathbf{2 4}$ & 60s & $\begin{array}{r}\text { Acute respiratory failure secondary to obesity hypoventilation } \\
\text { syndrome requiring non-invasive ventilation. }\end{array}$ & $\begin{array}{c}\text { Weekday } \\
\text { night }\end{array}$ & $\begin{array}{c}\text { Consultant 8, } \\
\text { Trainee 3 }\end{array}$ \\
\hline
\end{tabular}

\begin{tabular}{|c|c|c|c|c|}
\hline \multicolumn{5}{|c|}{ Referrals resulting in continuation of ward care } \\
\hline $\begin{array}{l}\text { Case } \\
\text { Number }\end{array}$ & Age & Clinical Vignette & Time & $\begin{array}{l}\text { Physician } \\
\text { Observed }\end{array}$ \\
\hline 25 & $40 \mathrm{~s}$ & Severe pneumonia with background diabetes and hypertension. & $\begin{array}{l}\text { Weekday } \\
\text { evening }\end{array}$ & Consultant $1^{*}$ \\
\hline 26 & $60 \mathrm{~s}$ & $\begin{array}{l}\text { Low platelets and small bowel obstruction in an } \\
\text { immunocompromised patient with leukaemia. }\end{array}$ & $\begin{array}{l}\text { Weekday } \\
\text { morning }\end{array}$ & Consultant $9^{*}$ \\
\hline 27 & $40 \mathrm{~s}$ & $\begin{array}{l}\text { Breathlessness, type one respiratory failure and oliguria in a } \\
\text { man with alcoholic liver disease. }\end{array}$ & $\begin{array}{l}\text { Weekday } \\
\text { morning }\end{array}$ & Consultant 2 \\
\hline 28 & $70 \mathrm{~s}$ & $\begin{array}{l}\text { Breathlessness in a lady with bronchiectasis and end stage } \\
\text { renal failure. }\end{array}$ & $\begin{array}{l}\text { Weekday } \\
\text { morning }\end{array}$ & Consultant 2 \\
\hline 29 & $50 \mathrm{~s}$ & $\begin{array}{l}\text { Cardiac arrest secondary to hypoglycaemia and severe non- } \\
\text { alcoholic fatty liver disease. Care withdrawn following return of } \\
\text { spontaneous circulation. }\end{array}$ & $\begin{array}{l}\text { Weekend } \\
\text { evening }\end{array}$ & $\begin{array}{l}\text { Consultant } 10 \\
\text { Trainee } 4\end{array}$ \\
\hline 30 & $60 \mathrm{~s}$ & $\begin{array}{l}\text { Reduced level of consciousness in an immunocompromised } \\
\text { patient following several ICU admissions. }\end{array}$ & $\begin{array}{l}\text { Weekday } \\
\text { morning }\end{array}$ & $\begin{array}{l}\text { Consultant } 11, \\
\text { Trainee } 5\end{array}$ \\
\hline 31 & $20 \mathrm{~s}$ & $\begin{array}{l}\text { Immonocompromised patient with breathlessness. Normal } \\
\text { investigations. }\end{array}$ & $\begin{array}{l}\text { Weekend } \\
\text { morning }\end{array}$ & Consultant $4^{*}$ \\
\hline 32 & $70 \mathrm{~s}$ & $\begin{array}{l}\text { Breathlessness and hypotension in a patient with inoperable } \\
\text { bladder cancer. Two previous ICU admissions for multi-organ } \\
\text { failure. }\end{array}$ & $\begin{array}{l}\text { Weekday } \\
\text { evening }\end{array}$ & $\begin{array}{l}\text { Consultant } 7 \\
\text { Trainee } 1\end{array}$ \\
\hline 33 & $60 \mathrm{~s}$ & $\begin{array}{l}\text { Persistent hypotension for one day following carotid } \\
\text { endarterectomy. }\end{array}$ & $\begin{array}{l}\text { Weekday } \\
\text { morning }\end{array}$ & Consultant $3^{*}$ \\
\hline 34 & $40 \mathrm{~s}$ & $\begin{array}{l}\text { Fast atrial fibrillation, pyrexia and consolidation in a patient with } \\
\text { a prosthetic aortic valve. Responds to beta-blocker therapy. }\end{array}$ & $\begin{array}{l}\text { Weekday } \\
\text { evening }\end{array}$ & Consultant $3^{*}$ \\
\hline 35 & $20 \mathrm{~s}$ & $\begin{array}{l}\text { Seizures requiring intubation in a parturient. Extubated in the } \\
\text { emergency department. }\end{array}$ & $\begin{array}{l}\text { Weekday } \\
\text { evening }\end{array}$ & Consultant $4^{*}$ \\
\hline 36 & $30 \mathrm{~s}$ & $\begin{array}{l}\text { Reduced consciousness due to administration of } 12 \mathrm{mg} \\
\text { lorazapam in an epileptic man. }\end{array}$ & $\begin{array}{l}\text { Weekday } \\
\text { night }\end{array}$ & $\begin{array}{l}\text { Consultant } 8 \text {, } \\
\text { Trainee } 3\end{array}$ \\
\hline 37 & $70 \mathrm{~s}$ & $\begin{array}{l}\text { Reduced consciousness and a metabolic acidosis due to } \\
\text { dehydration. }\end{array}$ & $\begin{array}{l}\text { Weekday } \\
\text { night }\end{array}$ & $\begin{array}{l}\text { Consultant } 8 \text {, } \\
\text { Trainee } 3\end{array}$ \\
\hline 38 & $60 \mathrm{~s}$ & $\begin{array}{l}\text { Severe COPD exacerbation with multiple co-morbidities and } \\
\text { medical team requiring full escalation. }\end{array}$ & $\begin{array}{l}\text { Weekday } \\
\text { evening }\end{array}$ & Consultant $1^{*}$ \\
\hline 39 & $70 \mathrm{~s}$ & Strangulated inguinal hernia with multiple co-morbidities. & $\begin{array}{l}\text { Weekday } \\
\text { morning }\end{array}$ & $\begin{array}{l}\text { Consultant } 1^{*} \text {, } \\
\text { Trainee } 7\end{array}$ \\
\hline
\end{tabular}




\begin{tabular}{|c|c|c|c|c|}
\hline 40 & $40 \mathrm{~s}$ & Pyrexia of unknown origin and tachycardia and tachyopnea. & $\begin{array}{l}\text { Weekday } \\
\text { evening }\end{array}$ & Consultant 6 \\
\hline 41 & $80 \mathrm{~s}$ & Hypotension following repair of hip fracture. & $\begin{array}{l}\text { Weekday } \\
\text { evening }\end{array}$ & $\begin{array}{l}\text { Consultant } 13^{*}, \\
\text { Trainee } 8\end{array}$ \\
\hline 42 & $60 \mathrm{~s}$ & $\begin{array}{l}\text { Relapsed acute lymphocytic leukaemia, pyrexia, hypotension } \\
\text { and tachycardia. }\end{array}$ & $\begin{array}{l}\text { Weekday } \\
\text { morning }\end{array}$ & $\begin{array}{c}\text { Consultant } 12^{*}, \\
\text { Trainee } 7\end{array}$ \\
\hline 43 & $80 \mathrm{~s}$ & $\begin{array}{l}\text { Recent laparotomy for ischaemic bowel with new hypotension } \\
\text { and tachyopnea. }\end{array}$ & $\begin{array}{l}\text { Weekday } \\
\text { morning }\end{array}$ & $\begin{array}{l}\text { Consultant } 14^{*}, \\
\text { Trainee } 7\end{array}$ \\
\hline 44 & $80 \mathrm{~s}$ & $\begin{array}{l}\text { Bronchiectasis, long-term oxygen therapy with hypotensions } \\
\text { and tachycardia and a do not resuscitate order. }\end{array}$ & $\begin{array}{l}\text { Weekend } \\
\text { evening }\end{array}$ & $\begin{array}{c}\text { Consultant } 10^{*} \text {, } \\
\text { Consultant } 11 \text {, } \\
\text { Trainee } 9\end{array}$ \\
\hline 45 & $80 \mathrm{~s}$ & Acute abdomen but no decision to operate. & $\begin{array}{l}\text { Weekend } \\
\text { evening }\end{array}$ & $\begin{array}{c}\text { Consultant } 10^{*} \text {, } \\
\text { Consultant } 11 \text {, } \\
\text { Trainee } 9\end{array}$ \\
\hline 46 & $70 \mathrm{~s}$ & $\begin{array}{l}\text { Hypotension during angiography. Blood pressure recorded } \\
\text { falsely low. }\end{array}$ & $\begin{array}{l}\text { Weekday } \\
\text { morning }\end{array}$ & Consultant 2 \\
\hline 47 & $70 \mathrm{~s}$ & Hypotension during dialysis. & $\begin{array}{l}\text { Weekday } \\
\text { morning }\end{array}$ & Consultant $13^{*}$ \\
\hline 48 & $20 \mathrm{~s}$ & $\begin{array}{l}\text { Post-partum respiratory failure and pulmonary oedema } \\
\text { secondary to pre-eclampsia }\end{array}$ & $\begin{array}{l}\text { Weekday } \\
\text { morning }\end{array}$ & $\begin{array}{c}\text { Consultant } 15^{*}, \\
\text { Trainee } 6\end{array}$ \\
\hline 49 & $40 \mathrm{~s}$ & Recurrent hypoglycaemia in a patient with ESRF. & $\begin{array}{l}\text { Weekday } \\
\text { morning }\end{array}$ & $\begin{array}{l}\text { Consultant } 16, \\
\text { Trainee } 10\end{array}$ \\
\hline 50 & $40 \mathrm{~s}$ & $\begin{array}{l}\text { Pyrexia of unknown origin, hypotension and poor compliance } \\
\text { with ward based care. }\end{array}$ & $\begin{array}{l}\text { Weekday } \\
\text { evening }\end{array}$ & $\begin{array}{l}\text { Consultant } 6 \text {, } \\
\text { Trainee } 11\end{array}$ \\
\hline 51 & $70 \mathrm{~s}$ & $\begin{array}{l}\text { Type one respiratory failure in an immunocompronised patient } \\
\text { with chronic myeloid leukaemia. }\end{array}$ & $\begin{array}{l}\text { Weekday } \\
\text { morning }\end{array}$ & $\begin{array}{l}\text { Consultant } 6 \text {, } \\
\text { Trainee } 12\end{array}$ \\
\hline 52 & $70 \mathrm{~s}$ & Respiratory distress in a patient with lung cancer. & $\begin{array}{l}\text { Weekday } \\
\text { evening }\end{array}$ & $\begin{array}{l}\text { Consultant } 4^{*}, \\
\text { trainee } 13\end{array}$ \\
\hline 53 & $60 \mathrm{~s}$ & $\begin{array}{l}\text { Acute abdomen with an ischaemic bowel requiring end of life } \\
\text { care. }\end{array}$ & $\begin{array}{l}\text { Weekday } \\
\text { morning }\end{array}$ & $\begin{array}{l}\text { Consultant } 9^{*} \\
\text { Trainee } 9\end{array}$ \\
\hline 54 & $70 \mathrm{~s}$ & Tachynopea in a patient with ESRF. & $\begin{array}{l}\text { Weekday } \\
\text { morning }\end{array}$ & Consultant $3^{*}$ \\
\hline 55 & $50 \mathrm{~s}$ & Tachyarrhythmia on CCU. & $\begin{array}{l}\text { Weekday } \\
\text { evening }\end{array}$ & Consultant $3^{*}$ \\
\hline 56 & $40 \mathrm{~s}$ & $\begin{array}{l}\text { ED requesting routine review of a brittle asthmatic with multiple } \\
\text { previous ICU admissions prior to ward transfer. }\end{array}$ & $\begin{array}{l}\text { Weekday } \\
\text { morning }\end{array}$ & $\begin{array}{l}\text { Consultant } 13^{*}, \\
\text { Trainee } 7\end{array}$ \\
\hline 57 & $60 \mathrm{~s}$ & Tachyarrhythmia on CCU. & $\begin{array}{l}\text { Weekday } \\
\text { evening }\end{array}$ & $\begin{array}{l}\text { Consultant } 5 \text {, } \\
\text { Trainee } 4\end{array}$ \\
\hline 58 & $70 \mathrm{~s}$ & $\begin{array}{l}\text { Hypotension and tachycardia in a patient with end stage } \\
\text { pancreatic cancer. }\end{array}$ & $\begin{array}{l}\text { Weekday } \\
\text { morning }\end{array}$ & Consultant $3^{*}$ \\
\hline 59 & $80 \mathrm{~s}$ & Lower gastrointestinal haemorrhage. & $\begin{array}{l}\text { Weekday } \\
\text { evening }\end{array}$ & Consultant $3^{*}$ \\
\hline 60 & $80 \mathrm{~s}$ & $\begin{array}{l}\text { Cardiac arrest in resus requiring RSI but not for interventional } \\
\text { treatment due to advanced malignancy. }\end{array}$ & $\begin{array}{l}\text { Weekday } \\
\text { morning }\end{array}$ & Consultant $4^{*}$ \\
\hline 61 & $20 \mathrm{~s}$ & Parturient with urinary-tract sepsis. & $\begin{array}{l}\text { Weekday } \\
\text { evening }\end{array}$ & Consutlant $12^{*}$ \\
\hline 62 & $70 \mathrm{~s}$ & Type one respiratory failure due to pneumonia. & $\begin{array}{l}\text { Weekday } \\
\text { morning }\end{array}$ & Consultant $13^{*}$ \\
\hline
\end{tabular}




\begin{tabular}{|c|c|c|c|c|}
\hline 63 & $60 \mathrm{~s}$ & $\begin{array}{l}\mathrm{AF} \text { and reduced consciousness in a patient with lung cancer } \\
\text { requiring a CT head. }\end{array}$ & $\begin{array}{l}\text { Weekday } \\
\text { morning }\end{array}$ & $\begin{array}{l}\text { Consultant } 4^{*}, \\
\text { Consultant } 13^{*}\end{array}$ \\
\hline 64 & $70 \mathrm{~s}$ & $\begin{array}{l}\text { Severe COPD with poor functional capacity requiring treatment } \\
\qquad \text { limitation. }\end{array}$ & $\begin{array}{l}\text { Weekday } \\
\text { morning }\end{array}$ & Consultant 7 \\
\hline 65 & $70 \mathrm{~s}$ & Tachycardia and tachyopnea on CCU. & $\begin{array}{l}\text { Weekday } \\
\text { evening }\end{array}$ & Consultant 10 \\
\hline 66 & $50 \mathrm{~s}$ & Type one respiratory failure. & $\begin{array}{l}\text { Weekday } \\
\text { night }\end{array}$ & Consultant 5 \\
\hline 67 & $80 \mathrm{~s}$ & $\begin{array}{l}\text { In-hospital cardiac arrest and transferred to theatre recovery for } \\
\text { end of life care. }\end{array}$ & $\begin{array}{l}\text { Weekday } \\
\text { night }\end{array}$ & $\begin{array}{l}\text { Consultant } 9^{*} \\
\text { Consultant } 11\end{array}$ \\
\hline 68 & $50 \mathrm{~s}$ & $\begin{array}{l}\text { Deranged blood gases noticed by psychiatrist when assessing } \\
\text { mental state of a patient. }\end{array}$ & $\begin{array}{l}\text { Weekday } \\
\text { morning }\end{array}$ & Consultant 6 \\
\hline 69 & $20 \mathrm{~s}$ & Pyrexia secondary to TB. & $\begin{array}{l}\text { Weekday } \\
\text { evening }\end{array}$ & Consultant $14^{*}$ \\
\hline 70 & $50 \mathrm{~s}$ & Hypokalaemia due to vomiting with difficult intravenous access. & $\begin{array}{l}\text { Weekday } \\
\text { night }\end{array}$ & $\begin{array}{l}\text { Consultant } 8^{*} \text {, } \\
\text { Trainee } 3\end{array}$ \\
\hline 71 & $90 \mathrm{~s}$ & Type one respiratory failure. & $\begin{array}{l}\text { Weekday } \\
\text { night }\end{array}$ & Consultant 17 \\
\hline
\end{tabular}

Consultant *; indicates a consultant who was subsequently interviewed 